\title{
Expression of DNA-dependent Protein Kinase and Its Relationship with Epidermal Growth Factor Receptor Signaling in Metastatic Cancer Cell Lines
}

\author{
Jee Young Hwang ${ }^{a}$, Sun Hee Kim ${ }^{1}$, Chi Dug Kang ${ }^{1}$ and Man Soo Yoon* \\ Department of Obstetrics \& Gynecology, ${ }^{1}$ Department of Biochemistry, College of Medicine, Pusan National University, Pusan 602-739, Korea \\ Received April 20, 2005 / Accepted May 18, 2005
}

\begin{abstract}
The genetic instability of cancer cells may be related to inappropriately activated DNA repair pathways. In present study, the modulated expression of DNA-dependent protein kinase (DNA-PK), a major DNA repair protein, in human cancer metastatic cells was tested. The expressions of Ku70/80, regulatory subunit of DNA-PK, and the Ku DNA-binding activity in various highly metastatic cell lines were higher than those in each parental cell line. Also, the expression of DNA-PKcs, catalytic subunit of DNA-PK, and the kinase activity of the whole DNA-PK complex in highly metastatic cells were significantly increased as compared to those of parental cells, suggesting that the enhanced DNA repair capacity of metastatic cells could be associated with aberrant use of DNA repair, which may mediate tumor progression and metastatic potential. Increased EGFR (epidermal growth factor receptor) signaling has been associated with tumor invasion and metastasis, and the linkage between EGFR-mediated signaling and DNA-PK has been suggested. This study showed that PKI166, the new EGFR tyrosine kinase inhibitor, modulated the expressions of Ku70/80 and DNA-PKcs and also revealed the chemosensitization effect of PKI166 against metastatic cells may be in part due to inhibition of Ku70/80. These results suggest that interference in EGFR signaling by EGFR inhibitor resulted in the impairment of DNA repair activity, and thus DNA-PK could be possible molecular targets for therapy against metastatic cancer cells.
\end{abstract}

Key words - DNA-PK, EGFR, metastatic cell lines, chemosensitization, DNA repair

Epidermal growth factor receptor (EGFR) is a $170 \mathrm{kDa}$ cell surface glycoprotein with tyrosine kinase activity. The EGFR pathway contributes to a number of processes important to cancer development and progression including cell proliferation, apoptosis, angiogenesis, and metastatic spread $[1,2]$. The EGFR plays an important role in the regulation of cell proliferation and differentiation[3]. Over-expression of EGFR is correlated with aggressive tumor growth, as well as with poor clinical outcome of common cancers in human, including breast, cervix, lung, and head and neck carcinomas[4-8].

There is increasing evidence that EGFR is associated with resistance to chemotherapeutic drugs and radiation. Transfection of EGFR into human breast cancer cells increased the resistance of these cells to cytotoxic drugs[9], and induction of radioresistance is predominantly associated with the activation of EGFR[10]. Therefore, blockade of EGFR leads to inhibition of cell cycle progression, induction of apoptosis, enhanced chemosensitivity[11-13] and inhibition

\section{*Corresponding author}

Tel : +82-51-240-7738, Fax : +82-51-248-1118

E-mail : msyoon@pusan.ac.kr

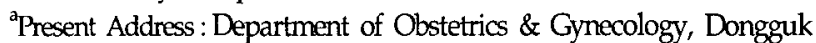
University College of Medicine, Kyung-ju 780-714, Korea of the repair efficiency of the damaged DNA[14].

It was reported that the EGFR physically interacted with DNA-dependent protein kinase (DNA-PK), an enzyme involved in repairing double strand breaks and $V(D) J$ recombination[15]. EGFR-mediated signaling could play a role in maintenance of the nuclear levels of DNA-PK, and the interference in EGFR signaling resulted in the impairment of DNA repair activity since efficient DNA repair in actively growing cells may require growth factor signaling. Genetic instability is much higher in metastatic clones than nonmetastatic clones and a comparison of DNA strand-break repair in a metastatic and a non-metastatic line showed more rapid repair in the former[16]. Aberrant use of DNA repair stimulated by growth factors may mediate tumor progression and heterogeneity as well as drug resistance and DNA repair capacity directly correlated with cell survival and metastatic potential[17].

A major mechanism by which cancer cells become resistant to ionizing radiation and chemotherapy drugs is enhancing DNA repair of the lesions. The invasive/metastatic cells develop drug resistance more readily than non-invasive/ metastatic cells. It has been reported that the intrinsic resistance of melanoma metastases to systemic chemotherapy 
may be associated with the enhanced DNA repair capacity of the cells[18]. Therefore, inhibition of DNA repair can re-sensitize tumors to chemotherapy and is increasingly exploited.

A better understanding of the molecular mechanisms that regulate the process of metastasis and of the complex interaction between the metastatic cells and host factors can provide a biological foundation for the design of more effective therapy for different cancers and cancer metastasis.

In the present study, the role of DNA-PK in metastatic cells and its association with EGFR-mediated signaling pathway in the cells as well as the chemosensitization effect of PKI166, new EGFR tyrosine kinase inhibitor, against metastatic cells were examined.

\section{Materials and methods}

\section{Reagents}

The following reagents were obtained from the listed sources and used at the concentrations indicated in the text. PKI166, C225 and taxol were kindly donated by Dr. IJ. Fidler (UT M. D. Anderson Cancer Center, Huston, TX). Vinblastine (VBL), adriamycin (ADR), bleomycin (BLM) and etoposide (VP-16) were obtained from Sigma. All other materials were obtained in the highest grade.

\section{Cell Lines and culture conditions}

The poorly metastatic A375 human melanoma cell line was originally established in culture from a lymph node metastasis of melanoma. The A375SM metastatic line was established from lung metastases produced by the A375 cells growing subcutaneously in nude mice. Low metastatic A375-C5 and highly metastatic A375-C28 clonal lines were derived from A375P by a limited dilution technique. These cell lines were maintained in culture $\left(5 \% \mathrm{CO}_{2}\right.$ and $95 \%$ air at $37^{\circ} \mathrm{C}$ ) as adherent monolayers in MEM supplemented with $10 \%$ fetal bovine serum, sodium pyruvate, nonessential amino acids, L-glutamine, and vitamin solution. KM12 cell line was established from a primary colorectal carcinoma classified as Dukes B2. The two metastatic cell lines, KM12SM and KM12L4A, which are derived from KM12. KM12SM (for spontaneous metastasis) cell line was derived from a liver metastasis after injection of the parental cell lines KM12 into the cecum of athymic mice. KM12L4A cell line is derived from a liver metastasis after injection of KM12SM into the spleen of athymic mice and repletion of this procedure three times. Human androgen-independent PC3 prostate adenocarcinoma cells and PC3M-MM2 cells, variants of PC3 selected for their highly metastatic potential were provided by Dr. I.J. Fidler. A highly metastatic LNCaPLN3 variant was isolated by intraprostatic injection of human androgen-dependent LNCaP prostate cancer cells. In the androgen-nonresponsive prostate carcinoma $\mathrm{PC} 3$ and its highly metastatic PC3M-MM2 cells lines were maintained in MEM supplemented with $10 \%$ fetal bovine serum, sodium pyruvate, nonessential amino acids, L-glutamine, and vitamin solution. The multidrug-resistant (MDR) varients, CT26/MDR cells isolated from mouse colon carcinoma cell line CT26 and MCF-7/MDR isolated from human breast carcinoma MCF-7 (provided by Dr. I. J. Fidler) were maintained in MEM supplemented with $10 \%$ fetal bovine serum.

\section{Growth inhibition assay}

Cells were seeded in 96 well plates at $2 \times 10^{4}$ cells $/ \mathrm{ml}$ and treated with each anticancer drug in the presence or absence of PKI166 for $96 \mathrm{~h}$, followed by the addition of $100 \mu \mathrm{l}$ of [3-(4,5-dimethyl-2-thiazolyl)-2,5-diphenyl tetrazolium bromide: MTT] solution $(5 \mathrm{mg} / \mathrm{ml})$ and the plates were incubated in the dark room for $4 \mathrm{hrs}$. The water - insoluble MTT-formazan crystals were dissolved in dimethyl sulfoxide, and reduction of MTT was determined at $570 \mathrm{~nm}$ using ELISA reader (Bio-Tec Instruments). $\mathrm{IC}_{50}$, the concentration of each anticancer drug for $50 \%$ inhibition of cell growth by after $96 \mathrm{~h}$ treatment, was determined from the growth inhibition plots.

\section{Western blot analysis}

Protein samples (50 $\mu \mathrm{g}$ of whole cell extracts) were separated by SDS-PAGE and blotted to nitrocellulose membrane. The membrane was incubated with antibody as specified, followed by secondary antibody conjugated with horseradish peroxidase. Specific antigen-antibody complexes were detected by enhanced chemiluminescence (Pierce). The affinity purified polyclonal antibody specific to the 70and $86-\mathrm{kDa} \mathrm{Ku}$ protein[19], the anti-DNA-PKcs, EGFR and $\beta$-tubulin antibodies were from Santa Cruz Biotechnology. Secondary antibodies were obtained from Boehringer Mannheim.

\section{DNA-PK assay}

The kinase activity of DNA-PK was determined using the Signa $\mathrm{TECT}^{\mathrm{TM}}$ DNA-dependent Protein Kinase Assay System from Promega. In brief, $10 \mu \mathrm{g}$ of nuclear extract was 
incubated with activator DNA, a biotinylated p53-derived peptide substrate, and $\left[{ }^{32} \mathrm{P}\right]$ ATP for $5 \mathrm{~min}$ at $30^{\circ} \mathrm{C}$. Adding termination buffer terminated the reaction. Each termination reaction sample was spotted onto $\mathrm{SAM} 2^{\mathrm{TM}}$ Biotin Capture Membrane and washed with $2 \mathrm{M} \mathrm{NaCl}$ and $2 \mathrm{M} \mathrm{NaCl}$ in $1 \% \mathrm{H}_{3} \mathrm{PO}_{4}$. The SAM2 ${ }^{\mathrm{TM}}$ membrane squares were analyzed using Molecular Imager System (Bio-Rad, Model GS 525).

\section{Electrophoretic mobility shift analysis (EMSA)}

Preparation of cell and the EMSA were performed as described by Kim et al[20]. Equal amount $(20 \mu \mathrm{g})$ of cellular proteins were incubated with ${ }^{32} \mathrm{P}$-labeled consensus oligonucleotide for Ku binding (GGGCCAAGAATCTTAGC AGTTTCGGG). The protein-bound and free oligonucleotides were electrophoretically separated on $4.5 \%$ native polyacrylamide gels in $0.5 \times$ TBE buffer [44.5 mM Tris ( $\mathrm{pH} 8.0$ ), 1 $\mathrm{mM}$ EDTA and $44.5 \mathrm{mM}$ boric acid] for $3 \mathrm{hrs}$ at $120 \mathrm{~V}$. The gels were dried and autoradiographed.

\section{Results}

\section{Increased expression of DNA-PK in metastatic cells}

It has been suggested that DNA repair capacity could be involved in the linkage with cell survival and metastatic potential[17]. The Ku70/80 heterodimer $(\mathrm{Ku})$, the regulatory subunit of DNA-PK, contributes to genomic integrity through its ability to bind DNA double-strand breaks and facilitates the repair by the non-homologous end-joining pathway [21]. Therefore, to evaluate the Ku DNA-binding activity of metastatic cells, various high metastatic cell lines of different tissue origins and each parental non-metastatic or poorly metastatic cells as control were tested by EMSA. All tested high metastatic cells showed high $\mathrm{Ku}$ DNA-binding activity as compared to parental cells, irrespective of tissue origin (Fig. 1). As shown in Fig 1a, all of the melanoma cell lines showed constitutive $\mathrm{Ku}$ DNA-binding activity, and the $\mathrm{Ku}$ activity of A375SM and A375-C28 cells which were known to be highly metastatic was significantly increased as compared to those of the poorly metastatic A375-C5 and A375 cells. Also, the constitutive $\mathrm{Ku}$ DNA-binding activity of metastatic colon cancer KM12SM and KM12L4A cells were markedly enhanced as compared to that of non-metastatic parental KM12 cells (Fig. 1b). To confirm this result, another metastatic cells of different origin were tested. The Ku DNAbinding activity of human prostate cancer PC3 and LNCaP cells were compared with that of their highly metastatic a

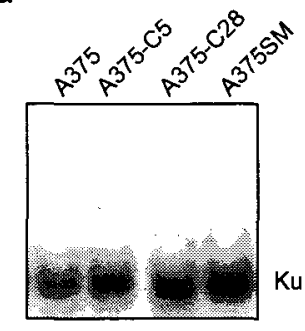

C

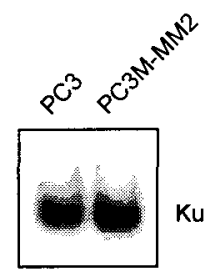

b

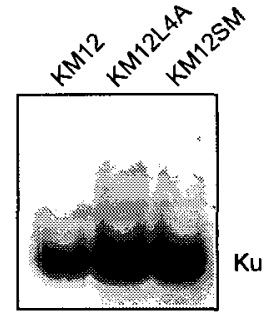

d

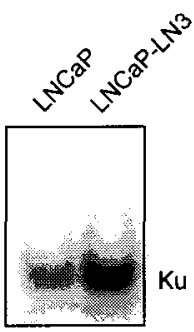

Fig. 1. Enhancement of Ku-DNA binding activity in metastatic cancer cells. Basal Ku-DNA binding activities in A375 and its metastatic varients (a), KM12 and its metastatic KM12SM and KM12L4A cells (b), PC3 and its metastatic PC3M-MM2 cells (c), and another prostate cancer cell line LNCaP and its metastatic LNCaP-LN3 cells (d) were assayed by EMSA.

PC3M-MM2 and LNCaP-LN3 cells (Fig. 1c and 1d). Ku DNA-binding activity of highly metastatic prostate cancer cells was significantly increased as compared to that of the corresponding non-metastatic parental cells, suggesting that metastatic phenotype could acquire high DNA repair capability.

To determine whether the different $\mathrm{Ku}$ DNA-binding activity in metastatic and non-metastatic cells was due to different productions of $\mathrm{Ku} 70$ and $\mathrm{Ku} 80$ proteins, the levels of Ku70/80, and the level of DNA-PKcs, catalytic subunit of DNA-PK, of these cells were examined by Western blot analysis. The levels of Ku protein and DNA-PKcs in metastatic tumor cells were significantly enhanced as compared to their poorly or non-metastatic counterparts (Fig. 2). The highly metastatic A375SM and A375-C28 cells showed an enhanced Ku70/80 and DNA-PKcs expression than those of the poorly metastatic A375-C5 and A375 cells, when $\beta$ -actin was used as reference control to show relative expression and loading difference (Fig. 2a, upper panel). The Ku80 expression of metastatic KM12SM cells was higher than that of KM12 cells but Ku70 level showed no significant difference between metastatic and non-metastatic cells, whereas the level of DNA-PKcs was enhanced as compared to that of KM12 cells. Also, the levels of Ku70/80 of PC3M- 
a
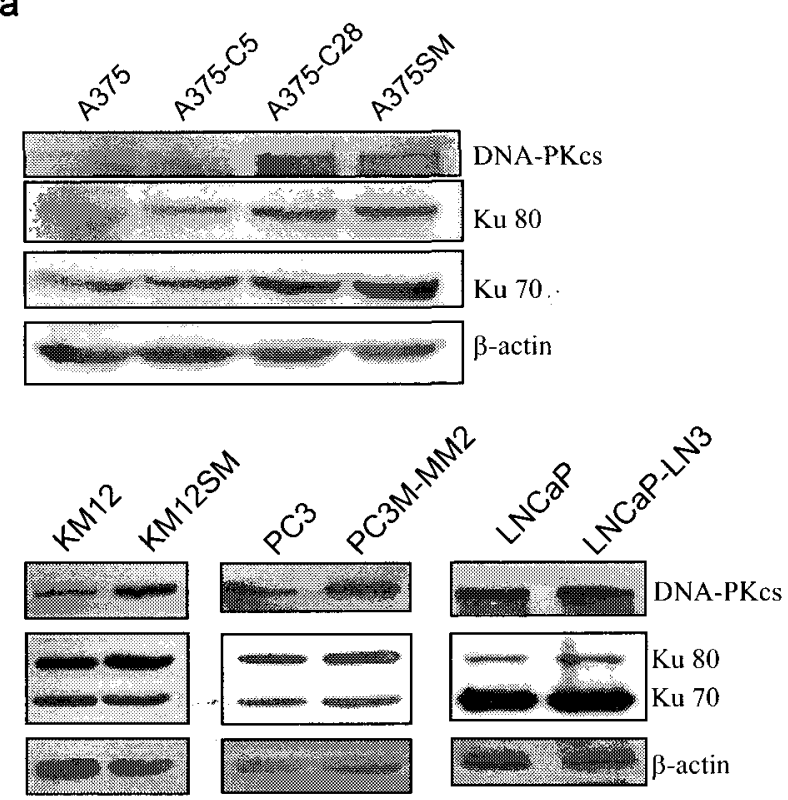

b

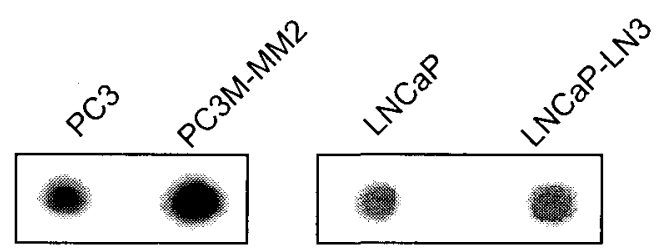

Fig. 2. Increased expression and activity of DNA-PK by acquiring metastatic phenotype. Basal Ku/DNA-PKcs expression levels of A375 and its metastatic variants, KM12 and its metastatic cells, PC3 and its metastatic cells, and LNCaP and its metastatic cells were assayed by Western blot analysis. Data were normalized to $\beta$-actin in order to show relative expression and loading differences (a). Basal DNA-PK activities in PC3 and LNCaP cells and each metastatic cells were determined (b).

MM2 and LNCaP-LN3 cells were higher than that of corresponding non-metastatic cells. The DNA-PKcs levels of high metastatic prostate cancer cell lines were significantly increased compared to those of non-metastatic counterparts when $\beta$-actin was used as reference control (Fig. 2a, lower panel). These results suggest the possibility that metastatic cells with the enhanced DNA-PK expression could repair DNA damage far rapidly than in non-metastatic cells.

In addition, to observe whether elevated levels of $\mathrm{Ku} 70$ / 80 and DNA-PKcs in metastatic cells lead to the increase of DNA-PK activity, the kinase activity of the whole DNAPK complex was compared in metastatic and non-metastatic counterparts. The LNCaP-LN3 and PC3M-MM2 cells showed an increase in DNA-PK activity compared with parental non-metastatic LNCaP and PC3 cells (Fig. 2b). The results also suggest the possibility that capacity of metastatic cells could associate with aberrant use of DNA repair, which may mediate tumor progression and metastatic potential.

\section{Effect of growth factors on DNA-PK expression in metaststic cells}

It has been shown that growth factors such as vascular endothelial growth factor (VEGF), platelet-derived growth factor (PDGF) and epidermal growth factor (EGF) significantly reduce the pro-apoptotic potency of chemotherapy[22-24]. On the other hand, activation of DNA-PK also prevents apoptosis[25]. Therefore, we examined whether the treatment of growth factor could modulate the expression of DNAPK in A375SM cells. Treatment of the cells with $50 \mathrm{ng} / \mathrm{ml}$ EGF resulted in abruptly enhanced Ku80 expression at $1 \mathrm{~h}$ after treatment, and also showed increased Ku70 expression under same condition (Fig. 3, left panel). We also tested if other growth factors modulate DNA-PK expression. Treatment of the cells with PDGF- $\beta(5 \sim 25 \mathrm{ng} / \mathrm{ml}$ for $2 \mathrm{~h})$ also enhanced the DNA- PKcs and Ku70 expressions but not
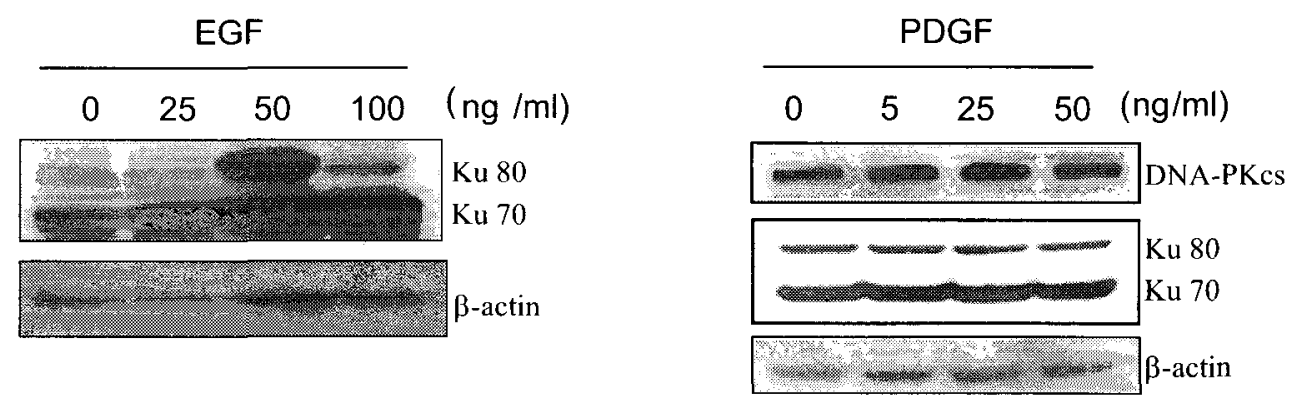

Fig. 3. Effect of growth factor on DNA-PK expression in A375SM cells. The cells were treated with the indicated doses of EGF for $1 \mathrm{~h}$ (a) or PDGF- $\beta$ for $2 \mathrm{~h}$ (b). Whole-cell extracts from growth factor-treated cells were subjected to Western blot analysis for determination of Ku70/80 or DNA-PKcs. Data were normalized to $\beta$-actin in order to show relative expression and loading differences. 
affect on Ku80 expression (Fig. 3, right panel). These results suggest a possibility that EGF known to up-regulate the cell survival could lead to the activation of DNA-PK.

Increased expression of epidermal growth factor receptor (EGFR) in metastatic or MDR cells, and modulation of DNA-PK expression by EGFR inhibitor

Increased EGFR signaling has been associated with tumor invasion and metastasis, and thus blockade of EGFR by EGFR tyrosine kinase inhibitor leads to inhibition of growth and metastasis of cancer cells[26,27]. It has been reported that there is the possibility of the linkage between EGFRmediated signaling and DNA-PK[15]. Therefore, we determined whether the expression of EGFR could be modulated in highly metastatic cells. As shown in Fig. 4a, various highly metastatic cells showed increased EGFR expression. A375SM and A375-C28 cells showed increased EGFR expression compared with poorly metastatic A375-C5 and A375 cells. Similar results were obtained in other metastatic cell lines. The EGFR expression of KM12SM, KM12L4A cells and PC3M-MM2 cells showed higher metastatic potential than that of each parental cell line. In addition, multidrug-resistant MCF-7/MDR and CT26/MDR cells also showed significantly enhanced EGFR and Ku70/80 expression compared to drug- sensitive parental MCF-7 and CT26 cells, respectively (Fig. 4b). These results indicate that increased expression of EGFR could be associated with acquirement of metastatic or MDR phenotype.

a

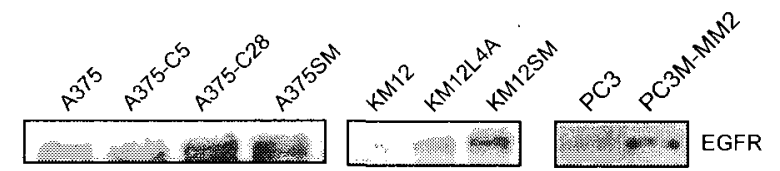

b

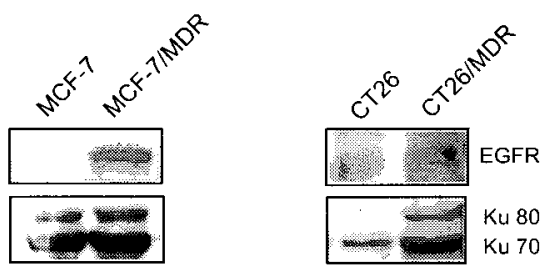

Fig. 4. Increased expression of epidermal growth factor receptor (EGFR) in metastatic or MDR cells. Basal EGFR expression levels of various metastatic and their parental cells (a), and basal EGFR and Ku expression levels of MDR and their parental cells (b) were assayed by Western blot analysis.
To determine whether new EGFR tyrosine kinase inhibitor, PKI166, could modulate the expression of DNA-PK components, the effect of PKI166 on the expressions of Ku70/ 80 and DNA-PKcs in A375SM and A375 cells was examined after exposure to increasing concentration of PKI166 for 90 min. Treatment with PKI166 $(0.25 \sim 1 \mu \mathrm{M})$ resulted in the decreased expressions of Ku80 and DNA-PKcs of these cells in dose-dependent manner. A375SM cells showed that the inhibition of PKI166 on the expressions of Ku70/80 and DNA-PKcs was more severe than A375 cells (Fig. 5a). To more confirm the interference in EGFR signaling pathway could affect on DNA-PK expression, it was checked if the expression of DNA-PK could be modulated by the treatment of the C225, anti-EGFR antibody, against A375 and A375SM cells. The C225 on the DNA-PK was more sensitive in A375SM cells than in A375 cells, and it inhibited the expression of DNA-PKcs significantly as well as that of Ku80 in A375SM cells (Fig. 5b). These results suggested that interference in EGFR signaling by EGFR inhibitor resulted in the impairment of DNA repair activity, and thus DNA-PK could be possible molecular targets for therapy against metastatic cancer cells.

Development of drug resistance in metastatic cells Some tumor cells selected for resistance to anticancer

a

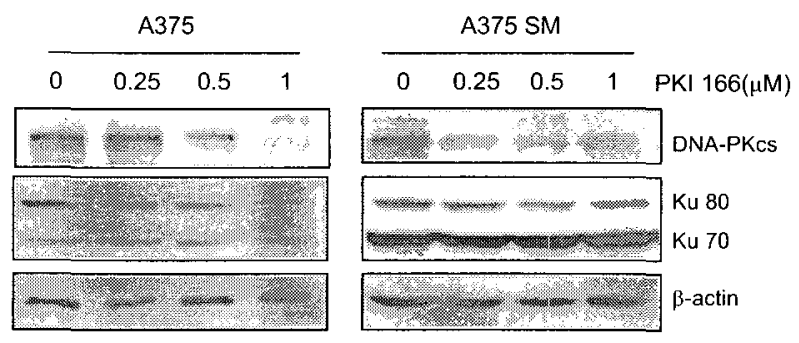

b

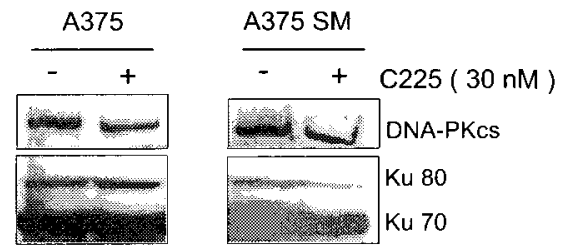

Fig. 5. Modulation of DNA-PK expression by EGFR inhibitor. A375 and its metastatic A375SM cells were treated with the indicated doses of PKI166 for $90 \mathrm{~min}$ (a) or C225(30 $\mathrm{nM})$ for $1 \mathrm{~h}(\mathrm{~b})$. Western blot analysis was done to measure the expression levels of Ku/DNA-PKcs of each cell line. Data were normalized to $\beta$-actin in order to show relative expression and loading differences. 
drugs are known to be relatively invasive/metastatic compared to non-resistant parental cells[28]. Controversially, no correlation between drug exposure/resistance and cancer invasion/metastasis has been reported[29].

In addition, up-regulation of DNA-PK:participates in the development of drug resistance[30]. Since metastatic cells showed increased DNA-PK expression as compared to parental cells, the drug sensitivities of metastatic cells of different tissue origin and their parental cells were compared. Various metastatic and parental cells were treated with each anticancer drug for $96 \mathrm{~h}$, and growth inhibition was determined by MTT assay. The results are summarized in Table 1. The metastatic KM12L4A and LNCaP-LN3 cells were 15.5- and 7.2-fold resistant to VP-16 than each parental cell line, respectively. The metastatic PC3M-MM2 and A375SM cells were 2.9- and 2.0-fold more resistant to VBL than their parental cells, respectively. But the drug sensitivities of ADR and BLM of metastatic cells were decreased only about 1.5 fold. These results indicate that metastatic cells could be resistant to some chemotherapeutic agents.

Table 1. Comparison of $\mathrm{IC}_{50}$ values of anticancer drugs in metastatic and its parental cells.

\begin{tabular}{|c|c|c|c|}
\hline Drugs & Cells & $\mathrm{IC}_{50}$ & $\begin{array}{l}\text { Drug resistance } \\
\left(\mathrm{IC}_{50}\right)^{\mathrm{M}} /\left(\mathrm{IC}_{50}\right)^{\mathrm{p}}\end{array}$ \\
\hline \multirow{4}{*}{$\begin{array}{l}\text { VP-16 } \\
(\mathrm{nM})\end{array}$} & KM12 & $20.0 \pm 1.1$ & \\
\hline & KM12L4A & $310 \pm 2.8$ & 15.5 \\
\hline & LNCaP & $140 \pm 12.3$ & \\
\hline & LNCaP-LN3 & $1010 \pm 35.0$ & 7.2 \\
\hline \multirow{4}{*}{$\begin{array}{l}\text { VBL } \\
(\mathrm{nM})\end{array}$} & PC3 & $4.5 \pm 0.4$ & \\
\hline & PC $3 \mathrm{M}-\mathrm{MM} 2$ & $13.0 \pm 1.2$ & 2.9 \\
\hline & A375 & $4.9 \pm 0.2$ & \\
\hline & A375SM & $9.6 \pm 0.3$ & 2.0 \\
\hline \multirow{4}{*}{$\begin{array}{c}\text { ADR } \\
(\mathrm{ng} / \mathrm{ml})\end{array}$} & KM12 & $6.4 \pm 0.4$ & \\
\hline & KM12L4A & $11.0 \pm 0.8$ & 1.7 \\
\hline & A375 & $3.8 \pm 0.2$ & \\
\hline & A375SM & $5.1 \pm 0.4$ & 1.3 \\
\hline \multirow{2}{*}{$\begin{array}{c}\text { BLM } \\
(\mu \mathrm{g} / \mathrm{ml})\end{array}$} & LNCaP & $1.0 \pm 0.1$ & \\
\hline & LNCaP-LN3 & $1.5 \pm 0.2$ & 1.5 \\
\hline
\end{tabular}

The concentration $\left(\mathrm{IC}_{50}\right)$ of each anticancer drug, which reduced cell growth by $50 \%$ after $96 \mathrm{~h}$ treatment, was determined from growth inhibition plots. Drug resistance values indicate the ratio of $\mathrm{IC}_{50}$ for drug against metastatic cells $(\mathrm{M})$ to the $\mathrm{IC}_{50}$ for drug against parental cells (P). Data are calculated as SEM (standard error of mean) of triplicate sample and are representative of at least two different experiments.

VP-16, etoposide; VBL, vinblastine; ADR, adriamycin; BLM, bleomycin
Synergistic effect of anticancer drug and PKI166 on the inhibition of $\mathrm{Ku}$ expression

In fact, it has been reported that the intrinsic resistance of metastatic cancer cells to systemic chemotherapy may be associated with the enhanced DNA repair capacity of the cells $[16,18]$, and it previously reported that Ku70/80 proteins affect the susceptibility to anticancer drugs[20]. Since PKI166 significantly inhibited the expression of DNA-PK, it was investigated if PKI166 could modulate the anticancer druginduced $\mathrm{Ku}$ expression. Exposure of $\mathrm{A} 375$ cells to $0.5 \mu \mathrm{M}$ PKI166 alone caused inhibition of Ku80, whereas significant inhibition of Ku80 was not occurred by $0.1 \mu \mathrm{g} / \mathrm{ml}$ taxol treatment. When the cells were treated with 0.1 or $0.5 \mu$ $\mathrm{g} / \mathrm{ml}$ taxol in the presence of $0.5 \mu \mathrm{M}$ PKI166, PKI166 caused a significant decrease in taxol-induced Ku80 levels. But, Ku70 level was not changed under same conditions (Fig. 6a). Treatment of KM12SM cells with $0.1 \mu \mathrm{M}$ PKI166 or 0.1 $\mu \mathrm{g} / \mathrm{ml}$ ADR alone did not affected the $\mathrm{Ku}$ expression, whereas exposure of $0.5 \mu \mathrm{g} / \mathrm{ml}$ ADR to the cells resulted in Ku70/80 inhibition. When the cells were treated with $0.1 \mu \mathrm{M}$ PKI166 and 0.1 or $0.5 \mu \mathrm{g} / \mathrm{ml}$ ADR, the synergistic effect of PKI166 and ADR on the inhibition of Ku expression was observed (Fig. 6b). Therefore, to test the possibility that

a

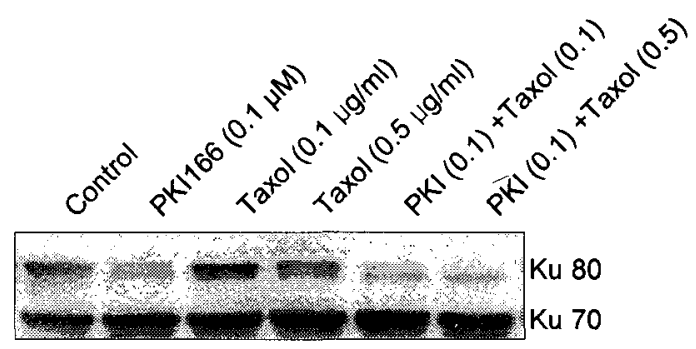

b

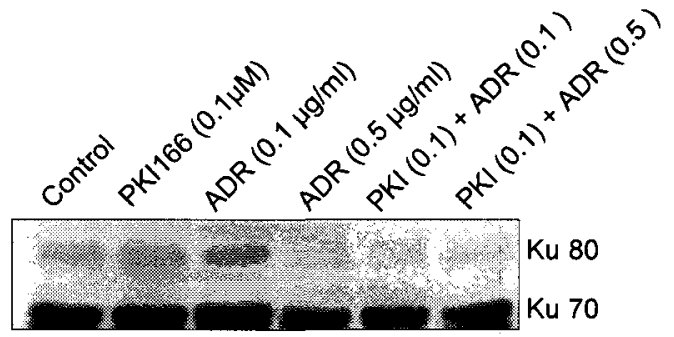

Fig. 6. Modulation of $\mathrm{Ku}$ expression in anticancer drug-treated metastatic cells by PKI166 treatment. The A375 cells were exposed to the indicated doses of taxol with and without $0.1 \mu \mathrm{M}$ PKI166 for $6 \mathrm{~h}$ (a), and the KM12SM cells were exposed to the indicated doses of adriamycin (ADR) with and without $0.1 \mu \mathrm{M}$ PKI166 for $6 \mathrm{~h}$ (b). Ku expression was determined by Western blot analysis. 
the synergistic inhibitory effect of PKI166 and anticancer drug on the $\mathrm{Ku}$ expression could enhance the cytotoxicity of the drug, the combination effect of PKI166 and anticancer drug were tested against various metastatic and MDR cells using MTT assay. KM12SM and KML4A metastatic cells showed $4.4 \sim 4.2$ fold enhancement of cytotoxicity to etoposide (VP-16) after combined treatment with $0.5 \mu \mathrm{M}$ PKI166 compared with the cytotoxicity of drug alone. When A375SM and A375-C28 metastatic cells were treated with anticancer drug (VP-16, taxol or ADR) in the presence or absence of $0.5 \mu \mathrm{M}$ PKI166 for $96 \mathrm{~h}$, the cytotoxicity of anticancer drugs against these highly metastatic cells were significantly enhanced about $2 \sim 13$ fold. Also, treatment of $0.5 \mu \mathrm{M}$ PKI166 sensitized CT26/MDR cells about 9.8-, 2.2-, 1.9-fold against VP-16, ADR and VBL, respectively (Table 2).

These results demonstrate that PKI166 could modulate the anticancer drug-induced $\mathrm{Ku}$ expression and that the chemosensitization effect of EGFR inhibitor against metastatic or MDR cells may be in part due to inhibition of $\mathrm{Ku}$ protein.

\section{Discussion}

A greater understanding of the complex multitude of factors involved in tumor angiogenesis and metastasis is fundamental to the development of potential therapeutics

Table 2. Potentiation of chemosensitivity by PKI166 in metastatic and MDR cells

\begin{tabular}{cccc}
\hline \multicolumn{3}{c}{ Drugs $\left(\mathrm{IC}_{50}\right)$} \\
\hline Cells & & PKI166 free & $+0.5 \mu$ M PKI166 \\
\hline KM12SM & & $350 \pm 21.0$ & $80.4 \pm 7.5(4.4)$ \\
KM12L4A & VP-16 $(\mathrm{nM})$ & $310 \pm 2.8$ & $73.8 \pm 5.0(4.2)$ \\
KM12 & & $20.0 \pm 1.1$ & $36.0 \pm 2.4(1.8)$ \\
\hline A375SM & VP-16 $(\mathrm{nM})$ & $26.0 \pm 1.5$ & $2.0 \pm 0.1(13.0)$ \\
\hline & Taxol $(\mathrm{nM})$ & $3.2 \pm 1.2$ & $1.6 \pm 0.2(2.1)$ \\
\hline A375-C28 & ADR(ng/ml) & $8.1 \pm 0.5$ & $1.6 \pm 0.1(5.1)$ \\
\hline CT26/MDR & VP-16 $(\mathrm{nM})$ & $108 \pm 9.2$ & $11.0 \pm 0.9(9.8)$ \\
\hline & ADR $(\mathrm{ng} / \mathrm{ml})$ & $11.0 \pm 1.3$ & $5.1 \pm 0.3(2.2)$ \\
\hline & VBL $(\mathrm{nM})$ & $4.0 \pm 0.2$ & $2.1 \pm 0.1(1.9)$ \\
\hline
\end{tabular}

Each cell line $\left(4 \times 10^{3}\right.$ cells/well) was treated with each anticancer drug for $96 \mathrm{~h}$ in the presence or absence of PKI166. Growth inhibition assay was performed by MTT method. Values in parentheses indicate the ratio of $\mathrm{IC}_{50}$ for drug alone to the $\mathrm{IC}_{50}$ for drug in the presence of PKI166. Data are calculated as SEM (standard error of mean) of triplicate sample and are representative of at least two different experiments. VP-16, etoposide; ADR, adriamycin; VBL, vinblastine to treat malignant disease. The correlation between overexpression of EGFR and clinically aggressive malignant disease renders EGFR a promising therapy target for many tumors[11,12]. The EGFR has emerged as a central molecular target for modulation in cancer therapeutics. Recently, the capacity of EGFR down-regulation to modify apoptosis, invasion capacity, angiogenesis, DNA damage repair, and cellular response to radiation and chemotherapy agents has been confirmed[13,14]. Indeed, the DNA repair mechanisms are important for the recovery of both normal and malignant tissues from radiation and chemotherapy[31]. In this study, we revealed that modulation of DNA repair protein by inhibition of EGFR signaling in metastatic cells could be target for cancer therapy against metastatic cancer cells.

There has been a growing body of opinion that tumor cells progress from a less malignant to a more malignant (metastatic) phenotype, due to genetic instability in generation of variant cell populations during metastatic spread[32,33]. It has also been suggested that genetic instability in metastatic cells could result from inappropriately activated DNA repair pathways stimulated by growth factors, which mediates tumor progression and heterogeneity as well as drug resistance[16]. Previously, it has been shown that enhanced expression of DNA-PK participates in the development of MDR, which protects cancer cells from a variety of drugs with different structure and function[30].

Present study showed that DNA-PK expression and the kinase activity of highly metastatic cells were significantly more enhanced than those of their parental non-metastatic or low metastatic cells. It seems likely that the enhanced DNA repair capacity of metastatic cells could be associated with aberrant use of DNA repair, which may mediate tumor progression and metastatic potential and participates in the development of drug resistance.

Increased EGFR signaling has been associated with tumor invasion and metastasis, and anti-EGFR therapies could target a large number of EGFR-expressing tumors. ZD1839, which blocked EGFR downstream signal transduction pathway, is a potential inhibitor of growth of cell lines expressing the EGFR[34] and anti-EGFR antibody C225 also has been reported to be active against chemotherapy and radiotherapy [4,11]. In this study, PKI166, the newly developed EGFR tyrosine kinase inhibitor, showed the inhibitory effect on DNA-PK expression, the kinase activity and the chemosensitization of anticancer drugs against metastatic cells, suggesting that blockade of EGFR leads to inhibition of the 
repair efficiency and it caused growth inhibition of metastatic cells. Furthermore, PKI166 was effective against MDR cells with enhanced DNA-PK expression as well as metastatic cells. It was revealed that the chemosensitization effect of EGFR inhibitor against metastatic or MDR cells is partially due to inhibition of $\mathrm{Ku}$ protein, and it means that blockade of EGFR linked with DNA-PK could be new target for cancer therapy against drug-resistant and metastatic cancer cells.

\section{References}

1. Carpenter G. 1987. Receptors for epidermal growth factor and other polypeptide mitogens. Annu Rev Biochem. 56, 881-914.

2. Chen, W. S., C. S. Lazar, M. Poenie, R. Y. Tsien, G. N. Gill and M.G. Rosenfeld. 1987. Requirement for intrinsic protein tyrosine kinase in the immediate and late actions of the EGF receptor. Nature 328, 820-823

3. Todaro, G. J., C. Fryling and J. E. De Larco. 1980. Transforming growth factors produced by certain human tumor cells: polypeptides that interact with epidermal growth factor receptors. Proc. Natl. Acad. Sci. U S A 77, 5258-5262.

4. Milas, L., K. Mason, N. Hunter, S. Petersen, M. Yamakawa, K. Ang, J. Mendelsohn and Z. Fan. 2000. In vivo enhancement of tumor radioresponse by $\mathrm{C} 225$ antiepidermal growth factor receptor antibody. Clin. Cancer Res. 6, 701-708.

5. Hu, G., W. Liu, J. Mendelsohn, L. M. Ellis, R. Radinsky, M. Andreeff and A. B. Deisseroth. 1997. Expression of epidermal growth factor receptor and human papillomavirus E6/E7 proteins in cervical carcinoma cells. Natl. Cancer Inst. 89, 1271-1276.

6. Iihara, K., H. Shiozaki, H. Tahara, K. Kobayashi, M. Inoue, S. Tamura, M. Miyata, H Oka, Y. Doki, and T. Mori. 1993. Prognostic significance of transforming growth factor-alpha in human esophageal carcinoma. Implication for the autocrine proliferation. Cancer 71, 2902-2909.

7. Grandis, J. R., M. F. Melhem, W. E. Gooding, R. Day, V. A. Holst, M. M. Wagener, S. D. Drenning and D. J. Tweardy. 1998. Levels of TGF-alpha and EGFR protein in head and neck squamous cell carcinoma and patient survival. Natl. Cancer Inst. 90, 824-832.

8. Klijn, J. G., P. M. Berns, P. I. Schmitz and J. A. Foekens. 1992. The clinical significance of epidermal growth factor receptor (EGF-R) in human breast cancer: a review on 5232 patients. Endocr. Rev. 13, 3-17.

9. Dickstein, B. M., K. Wosikowski and S. E. Bates. 1995. Increased resistance to cytotoxic agents in ZR75B human breast cancer cells transfected with epidermal growth factor receptor. Mol. Cell Endocrinol. 110, 205-211.

10. Balaban, N., J. Moni, M. Shannon, L. Dang, E. Murphy and T. Goldkorn. 1996. The effect of ionizing radiation on signal transduction: antibodies to EGF receptor sensitize A431 cells to radiation. Biochim. Biophys. Acta 1314, 147-156.

11. Mendelsohn, J. 1997. Epidermal growth factor receptor inhibition by a monoclonal antibody as anticancer therapy. Clin. Cancer Res. 3, 2703-2707.

12. Fan, Z., J. Baselga, H. Masui and J. Mendelsohn. 1993. Antitumor effect of anti-epidermal growth factor receptor monoclonal antibodies plus cis-diamminedichloroplatinum on well-established A431 cell xenografts. Cancer Res. 53, 4637-4642.

13. Schmidt, M. and R. B. Lichtner. 2002. EGF receptor targeting in therapy-resistant human tumors. Drug Resist. Updat. 5, 11-18.

14. Huang. S. M. and P. M. Harari. 2000. Modulation of radiation response after epidermal growth factor receptor blockade in squamous cell carcinomas: inhibition of damage repair, cell cycle kinetics, and tumor angiogenesis. Clin. Cancer Res. 6, 2166-2174.

15. Bandyopadhyay, D., M. Mandal, L. Adam, J. Mendelsohn and R. Kumar. 1998. Physical interaction between epidermal growth factor receptor and DNA-dependent protein kinase in mammalian cells. J. Biol. Chem. 273, 1568-1573.

16. Harris, A. L. 1985. DNA repair: relationship to drug and radiation resistance, metastasis and growth factors. Int. J. Radiat. Biol. Relat. Stud. Phys. Chem. Med. 48, 675-690.

17. Usmani, B. A., J. Lunec and G. V. Sherbet. 1993. DNA repair and repair fidelity in metastatic variants of the B16 murine melanoma. J. Cell Biochem. 51, 336-344.

18. Wei, Q., L. Cheng, K. Xie, C. D. Bucana and Z. Dong. 1997. Direct correlation between DNA repair capacity and metastatic potential of K-1735 murine melanoma cells. J. Invest. Dermatol. 108, 3-6.

19. Yang, S. H., A. Nussenzweig, W. H. Yang, D. Kim and G. C. Li. 1996. Cloning and characterization of Rat Ku70: Involvement of $\mathrm{Ku}$ autoantigen in the heat-shock response. Rad. Res. 146, 603-611.

20. Kim, S. H., D. Kim, J. S. Han, C. S. Jeong, B. S. Chung, C. D. Kang and G. C. Li. 1999. Ku autoantigen affects the susceptibility to anticancer drugs. Cancer Res. 59, 4012-4017.

21. Walker, J. R., R. A. Corpina and J. Goldberg. 2001. Structure of the $\mathrm{Ku}$ heterodimer bound to DNA and its implications for double-strand break repair. Nature 412, 607-614.

22. Sweeney, P., T. Karashima, S. J. Kim, D. Kedar, B. Mian, S. Huang, C. Baker, Z. Fan, D. J. Hicklin, C. A. Pettaway and C. P. Dinney. 2002. Anti-vascular endothelial growth factor receptor 2 antibody reduces tumorigenicity and metastasis in orthotopic prostate cancer xenografts via induction of endothelial cell apoptosis and reduction of endothelial cell matrix metalloproteinase type 9 production. Clin. Cancer Res. 8, 2714-2724.

23. Sano, H., Y. Ueda, N. Takakura, G. Takemura, T. Doi, H. Kataoka, T. Murayama, Y. Xu, T. Sudo, S. Nishikawa, S. Nishikawa, H. Fujiwara, T. Kita and M. Yokode. 2002. Blockade of platelet-derived growth factor receptor-beta pathway induces apoptosis of vascular endothelial cells and disrupts glomerular capillary formation in neonatal mice. Am. J. Pathol. 161, 135-143.

24. Nakajima, M., K. Kashiwagi, J. Ohta, S. Furukawa, K. Hayashi, T. Kawashima and Y. Hayashi. 1994. Nerve growth 
factor and epidermal growth factor rescue PC12 cells from programmed cell death induced by etoposide: distinct modes of protection against cell death by growth factors and a protein-synthesis inhibitor. Neurosci. Lett. 176, 161-164.

25. Bharti, A., S. K. Kraeft, M. Gounder, P. Pandey, S. Jin, Z. M. Yuan, S. P. Lees-Miller, R. Weichselbaum, D. Weaver, L.B. Chen, D. Kufe and S. Kharbanda. 1998. Inactivation of DNA-dependent protein kinase by protein kinase $C$ delta: implications for apoptosis. Mol. Cell Biol. 18, 6719-6728.

26. Lu, Z., G. Jiang, P. Blume-Jensen and Hunter, T. 2001. Epidermal growth factor-induced tumor cell invasion and metastasis initiated by dephosphorylation and downregulation of focal adhesion kinase. Mol. Cell Biol. 21, 4016-4031.

27. Solorzano, C. C., C. H. Baker, R. Tsan, P. Traxler, P. Cohen, E. Buchdunger, J. J. Killion and I. J. Fidler. 2001. Optimization for the blockade of epidermal growth factor receptor signaling for therapy of human pancreatic carcinoma. Clin. Cancer Res. 7, 2563-2572.

28. Liang, Y., P. Meleady, I. Cleary, S. McDonnell, L. Connolly and M. Clynes. 2001. Selection with melphalan or paclitaxel (Taxol) yields variants with different patterns of multidrug resistance, integrin expression and in vitro invasiveness. Eur. J. Cancer 37, 1041-1052.

29. Liang, Y., S. McDonnell and M. Clynes. 2002. Examining the relationship between cancer invasion/metastasis and drug resistance. Curr. Cancer Drug Targets 2, 257-277.

30. Kim, S. H., J. H. Um, D. W. Kim, B. H. Kwon, D. W. Kim, B. S. Chung and C. D. Kang. 2000. Potentiation of chemosensitivity in multidrug-resistant human leukemia CEM cells by inhibition of DNA-dependent protein kinase using wortmannin. Leuk. Res. 11, 917-925.

31. Sartor. C. I. 2000. Biological modifiers as potential radiosensitizers: targeting the epidermal growth factor receptor family. Semin. Oncol. 27, 15-20

32. Usmani, B. A. and G. V. Sherbet. 1996. Homologous recombination in variants of the B16 murine melanoma with reference to their metastatic potential. J. Cell Biochem. 61, 1-8.

33. Webb, C. P. and G. F. 2000. Vande Woude. Genes that regulate metastasis and angiogenesis. J. Neurooncol. 50, 71-87.

34. Baselga, J. 2002. Targeting the epidermal growth factor receptor with tyrosine kinase inhibitors: small molecules, big hopes. J. Clin. Oncol. 20, 2217-2219.

\title{
초록 : DNA-PK 및 표피성장인자수용체의 신호전달이 암전이에 미치는 영향
}

\author{
황지영 · 김선희 ${ }^{1}$ - 강치덕 ${ }^{1}$. 윤만수 ${ }^{*}$ \\ (부산대학교 의과대학 산부인과학교실, ${ }^{1}$ 생화학교실)
}

암세포의 유전적 불안정성은 부적절하게 활성화된 DNA 수복경로와 관련되어 있다. 전이성 암은 높은 유전적 불안정성을 나타내는데, 이와 관련하여 본 연구에서는 전이성 암세포에서의 중요한 DNA 수복 단백질의 하나인 DNA-의존성 단백질 키나아제(DNA-PK)의 발현 변화를 조사하였다. 여러 종류의 전이도가 다른 암세포들을 대상 으로 한 실험에서 전이성 암세포들은 각각의 모세포에 비하여 DNA-PK 성분의 조절 소단위인 Ku70/80의 발현 및 Ku의 DNA 결합 활성이 증강되어 있었다. 또한 DNA-PK의 촉매 소단위인 DNA-PKcs의 발현 및 whole DNA-PK 복합체의 kinase의 활성도 전이도가 큰 암세포에서 그 모세포보다 증강되어 있음을 알 수 있어, 전이성 암세포의 증강된 DNA 수복능은 부적절한 DNA 수복을 일으켜 암의 진행 및 전이를 촉진시키는 원인이 될 수 있음 을 시사하였다. 한편 암세포의 표피성장인자수용체의 신호전달의 증강은 암의 침윤과 전이에 관련되어 있으며, DNA-PK의 기능에도 영향을 줄 수 있는 가능성이 보고 된 바 있는데, 본 연구에서는 표피성장인자수용체의 신호전 달과 DNA-PK의 관련성을 명확히 밝히기 위하여 새로 개발된 EGFR tyrosine kinase inhibitor인 PKI166의 DNA-PK의 활성에 미치는 영향을 조사하였다. PKI166는 Ku70/80 및 DNA-PKcs의 발현을 억제하였고 이와 관련하 여 전이성 및 항암제 다제내성 암세포에서 PKI166에 의하여 항암제에 대한 감수성을 증가시켜 항암제 내성을 나타 내는 전이성 암세포 대한 치료법 연구에 DNA-PK가 분자적 표적이 될 수 있음을 밝혔다. 